\section{Jurnal Kimia Sains dan Aplikasi Journal of Scientific and Applied Chemistry}

Journal homepage: http://ejournal.undip.ac.id/index.php/ksa

\title{
The Chemical Characteristics of Iron Oxide/Carbon Synthesized by the Arc Discharge Method in Liquid Media with the Addition of Ammonia
}

\author{
Indah Retnosari ${ }^{a}$, Ikrima Nur Hayati ${ }^{\mathrm{a}}$, Amalia Amalia ${ }^{a}$, Sri Hastuti, Teguh Endah Saraswati ${ }^{\mathrm{a},{ }^{*}}$ \\ a Program Studi Kimia, Fakultas Matematika dan Ilmu Pengetahuan Alam, Universitas Sebelas Maret, Surakarta, Indonesia \\ * Corresponding author: teguh@mipa.uns.ac.id \\ https://doi.org/10.14710/jksa.21.4.166-170
}

\section{Article Info \\ Article history: \\ Received: 13 August 2018 Revised: 1 September 2018 \\ Accepted: 6 October 2018 Online: 31 October 2018}

Keywords: iron oxide; carbon; ammonia; arc discharge; chemical characteristics

Kata Kunci: besi oksida; karbon; amonia; arc discharge; karakter kimia

\begin{abstract}
The chemical characteristics of composite material of iron oxide with carbon synthesized by arc discharge method in liquid medium have been identified. The liquid medium used in the method was ethanol with ammonia addition. The chemical characteristics of the resulting product were studied by Fourier transform infrared spectroscopy (FTIR) and energy dispersive X-ray (EDX). The morphology of the material was studied by scanning electron microscopy (SEM) and transmission electron microscopy (TEM). The observed materials have a spherical and orderly structure. The FTIR spectra profile shows the peaks of N-H and C-N. The amino groups coming from ammonia as a liquid medium during arc discharge were supposed to have been covalently attached to carbon materials composited with iron oxide. The elemental analysis of EDX confirms the presence of nitrogen elements that were not found on the materials synthesized in arc discharge without ammonia addition.
\end{abstract}

\section{Abstrak}

Karakter kimia material komposit besi oksida dengan karbon tersintesis dengan metode arc discharge dalam media cair telah diidentifikasi. Media cair yang digunakan dalam metode tersebut adalah etanol dengan penambahan amonia. Karakter kimia hasil sintesis dipelajari dengan spektroskopi fourier transform infrared (FTIR) dan energy dispersive $\mathrm{X}$-ray (EDX). Morfologi material hasil sintesis dipelajari dengan scanning electron microscope (SEM) dan transmission electron microscopy (TEM). Material yang teramati memiliki struktur yang sperikal dan teratur. Profil spectra FTIR menunjukkan puncak N-H dan C-N. Dari hasil ini, amino group dari amonia sebagai media cair dalam arc discharge diduga telah melekat secara kovalen pada material karbon yang telah terkomposit bersama dengan besi oksida. Data elemen dari EDX memperkuat keberadaan nitrogen yang tidak ditemukan pada hasil sintesis menggunakan media cair etanol tanpa penambahan amonia.

\section{Pendahuluan}

Seiring dengan perkembangan teknologi, kebutuhan akan sifat unik dari nanomaterial semakin meningkat seperti memiliki biokompatibiltas terhadap tubuh dan memiliki kapasitas tinggi dalam mengadsorbsi [1]. Salah satu material yang banyak digunakan adalah nanopartikel magnetik. Aplikasi nanopartikel magnetik dapat sangat luas dalam bidang bioteknologi sebagai biological separation, magnetic resonance imaging (MRI) 
agents, magnetic drug delivery system [2], dan magnetic hyperthermia treatment [3]. Beberapa contoh nanopartikel magnetik yang dapat dikembangkan adalah besi, kobalt, nikel dan besi oksida seperti magnetit $\left(\mathrm{Fe}_{3} \mathrm{O}_{4}\right)$ [4-6], hematit $\left(\alpha-\mathrm{Fe}_{2} \mathrm{O}_{3}\right)$ dan maghemit $\left(\gamma-\mathrm{Fe}_{2} \mathrm{O}_{3}\right)$ [7]. Karakteristik dari besi oksida adalah kebanyakan dijumpai dalam keadaan trivalen, kelarutannya rendah (biokompatibilitasnya rendah), paramagnetik [8], luas permukaan besar, toksisitas dan biodegradabilitas yang relatif rendah [4].

Material besi oksida $\mathrm{Fe}_{3} \mathrm{O}_{4}$ mudah untuk disintesis. Namun, $\mathrm{Fe}_{3} \mathrm{O}_{4}$ ini juga bersifat tidak stabil terhadap oksidasi di udara. Solusi untuk memperbaiki stabilitas material adalah dengan memberikan lapisan pendukung atau coating pada material membentuk struktur inti sel yaitu nanomaterial sebagai inti yang dilapisi material pendukung [9]. Material pendukung yang sering digunakan adalah karbon karena memiliki biokompatibilitas yang baik, stabilitas yang tinggi mencegah terjadinya oksidasi dan mudah difungsionalisasi [10]. Selain itu lapisan karbon pada nanomaterial dapat menghilangkan toksisitas dan dapat ditambahkan therapeutic agent, targeting atau fluorophore agent tergantung kebutuhannya [11]. Sintesis dan modifikasi nanomaterial $\mathrm{Fe}_{3} \mathrm{O}_{4} / \mathrm{C}$ dapat dilakukan dengan menggunakan metode arc discharge pada tekanan rendah $[1]$.

Untuk meningkatkan biokompatibilitas saat diaplikasikan di lingkungan biologi, modifikasi permukaan nanomaterial diperlukan dan dapat dilakukan dengan penambahan gugus fungsi bioactive seperti $-\mathrm{NH}_{2}$ dan $-\mathrm{COOH}$. Gugus fungsi bioactive diharapkan dapat menempel pada permukaan nanopartikel sehingga mengubah karakter permukaan nanopartikel yang semula bersifat hidrofobik menjadi bersifat hidrofilik [12].

Saraswati [1] telah melakukan modifikasi permukaan pada tahapan terpisah setelah melakukan sintesis dengan metode arc discharge. Akan tetapi, sintesis dan modifikasi $\mathrm{Fe}_{3} \mathrm{O}_{4} / \mathrm{C}$ memungkinkan dilakukan dalam satu tahapan menggunakan metode arc discharge yang dilakukan dalam media cair. Variasi media cair yang digunakan akan memberikan karakter permukaan yang berbeda. Sintesis dan mofikasi $\mathrm{Fe}_{3} \mathrm{O}_{4} / \mathrm{C}$ menggunakan arc discharge dalam media cair belum banyak dikaji lebih lanjut, khususnya terkait dengan karakter permukaan dan gugus fungsi yang dimiliki pada material hasil sintesis.

Oleh karena itu, artikel ini mempelajari hasil sintesis dan modifikasi $\mathrm{Fe}_{3} \mathrm{O}_{4} / \mathrm{C}$ yang dilakukan dalam satu tahapan menggunakan arc discharge dalam media cair etanol dengan dan tanpa penambahan amonia. Variasi penambahan amonia dalam media cair diyakini akan memberikan hasil karakter permukaan yang berbeda signifikan yang dapat dipelajari dengan menggunakan FTIR, TEM dan dikaitkan dengan hasil analisis SEM bergabung dengan analisis kuantitatif EDX.

\section{Metode eksperimen}

\section{Alat dan Bahan}

Bahan yang digunakan dalam penellitian ini adalah elektroda karbon Qingdao Tenry Carbon Co. Ltd ((Karbon grafit $99 \%$; densitas 1,95 gr/cm3; electrical resistance 7-10 ohm; dimensi elektroda tak berlubang $(\mathrm{d}=10 \mathrm{~mm}, \mathrm{p}=50$ $\mathrm{mm})$; dimensi elektroda berlubang $\left(\mathrm{d}_{\text {inner }}=7 \mathrm{~mm}\right.$, $\mathrm{d}_{\text {outer }}=$ $10 \mathrm{~mm} ; \mathrm{p}=100 \mathrm{~mm})$ ); besi oksida $\left(\mathrm{Fe}_{3} \mathrm{O}_{4}\right)$ komersial; grafit Merck (Karbon molar mass 12,01 g/mol); etanol 70\%; akuades; amonia 25\%; dan fruktosa. Alat yang digunakan dalam penelitian ini adalah seperangkat arc discharge; FTIR (Fourier Transform Infrared Spectroscopy) Shimadzu 6000; SEM (Scanning Electron Microscopy) Zeiss EVO MA10; Neraca Analitik Sartorius BP 110 (maks : 110 gram; min : 0,001 gram); DC power supply (maks: $110 \mathrm{~A} ;$ min: $10 \mathrm{~A}$; $20,8 \mathrm{~V}$ ); furnace/hotplate; pengungkit; statif; klem; tabung reaksi; sentrifuse dan peralatan berbahan gelas maupun polimer (Pyrex dan Duran).

\section{Prosedur}

\section{Sintesis $\mathrm{Fe}_{3} \mathrm{O}_{4} / \mathrm{C}$ dengan penambahan amonia}

Metode yang digunakan adalah metode arc discharge dalam media cair. Metode ini menggunakan dua elektroda yaitu anoda dan katoda. Pada katoda dibuat runcing sedangkan pada anoda dilubangi. Anoda diisi dengan karbon: $\mathrm{Fe}_{3} \mathrm{O}_{4}$ :fruktosa pada perbandingan massa 3:1:2. Anoda dan katoda dipasang dengan jarak 1-5 mm. Anoda dan katoda diusahakan dekat dengan jarak yang sangat kecil tapi tidak menempel. Hal ini dilakukan supaya terjadi loncatan ion-ion listrik yang ditandai dengan loncatan bunga api. Arus dan elektoda baik anoda maupun katoda di set-up di dalam gelas beker berisi media larutan. Metode arc discharge dilakukan dalam media cair etanol $50 \%$ dan amonia $10 \%$ dalam total volume $300 \mathrm{~mL}$ dengan arus sekitar $10 \mathrm{~A}$. Proses ini berlangsung dari munculnya bunga api hingga tidak terlihat lagi dalam waktu antara 10-15 menit. Hasil arc yang diperoleh kemudian dipisahkan antara padatan dan larutan menggunakan sentrifuse. Padatan basah yang diperoleh kemudian dikeringkan sehingga menjadi padatan yang kering.

\section{Karakterisasi struktur permukaan dan gugus fungsi}

Padatan hasil arc discharge dikarakterisasi gugus fungsi menggunakan Fourier Transform Infra Red (FTIR) dan struktur morfologi permukaan menggunakan Scanning Electron Microscope (SEM), Transmission Electron Microscope (TEM) serta analisa kuantitatif menggunakan Energy Dispersive X-ray (EDX).

\section{Hasil dan Pembahasan}

Proses sintesis $\mathrm{Fe}_{3} \mathrm{O}_{4} / \mathrm{C}$ telah dilakukan dengan menggunakan metode arc discharge dalam larutan etanol $50 \%$ dengan penambahan dan tanpa penambahan amonia $10 \%$ pada total larutan $300 \mathrm{~mL}$ dengan perbandingan volume 1:1 (v/v). Penambahan amonia bertujuan untuk memodifikasi permukaan material 
produk yang dihasilkan sehingga mengandung gugus fungsional yang meningkatkan biokompatibilitas terhadap tubuh. Proses arc discharge mengakibatkan pada kedua elektroda yang dipasang terjadi loncatan ion-ion listrik yang ditandai dengan terjadinya loncatan bunga api yang menimbulkan gelembung gas seiring terjadinya peningkatan suhu. Gelembung gas ini terjadi karena adanya reaksi antara elektroda dan media cair yang digunakan. Setelah proses arc discharge selesai, hasil arc discharge yang berwarna hitam dipisahkan antara padatan dan larutan menggunakan sentrifuse. Padatan yang sudah terpisah kemudian dikeringkan menjadi padatan kering $\mathrm{Fe}_{3} \mathrm{O}_{4} / \mathrm{C}$ untuk media cair tanpa penambahan amonia dan $\mathrm{Fe}_{3} \mathrm{O}_{4} / \mathrm{C}-\mathrm{NH}_{2}$ untuk media cair dengan penambahan amonia yang keduanya berwarna hitam. Penambahan amonia kedalam media cair diketahui dapat memodifikasi $\mathrm{Fe}_{3} \mathrm{O}_{4} / \mathrm{C}$ dengan penambahan gugus fungsi $-\mathrm{NH}_{2}$ sehingga terjadi perubahan struktur morfologi permukaan yang dapat dilihat dari karakterisasi berikut.

Karakterisasi menggunakan SEM bertujuan untuk mengetahui gambaran morfologi struktur permukaan dari material hasil arc discharge. Hasil analisa ditunjukkan pada Gambar 1 dan 2. Pada perbesaran yang sama, morfologi dari hasil analisa SEM pada Gambar 1 (A dan B) menunjukkan bahwa partikel produk memiliki morfologi bongkahan yang sama dalam ukuran mikro yang diduga merupakan kumpulan dari nanomaterial produk. Untuk studi struktur dan morfologi yang lebih detil, analisa pencintraan produk dianalisa lanjut dengan TEM sebagaimana yang ditunjukkan pada Gambar 2 (A dan B). Pencintraan dengan TEM menunjukkan material produk $\mathrm{Fe}_{3} \mathrm{O}_{4} / \mathrm{C}$ (Gambar 2(A)) dan $\mathrm{Fe}_{3} \mathrm{O}_{4} / \mathrm{C}-\mathrm{NH}_{2}$ (Gambar 2(B)) memiliki struktur yang sperikal dan teratur dengan skala nanometer dimana sebagian $\mathrm{Fe}_{3} \mathrm{O}_{4} / \mathrm{C}-\mathrm{NH}_{2}$ hasil sintesis dengan penambahan amonia berukuran lebih kecil daripada $\mathrm{Fe}_{3} \mathrm{O}_{4} / \mathrm{C}$ hasil sintesis tanpa penambahan amonia. Penambahan amonia saat proses sintesis diduga berperan pada modifikasi permukaan material. Hal ini berpengaruh pada tidak terjadinya aglomerasi $\mathrm{Fe}_{3} \mathrm{O}_{4}$ sehingga partikel komposit $\mathrm{Fe}_{3} \mathrm{O}_{4} / \mathrm{C}$ hasil sintesis dengan penambahan amonia, berada pada ukuran yang lebih kecil.
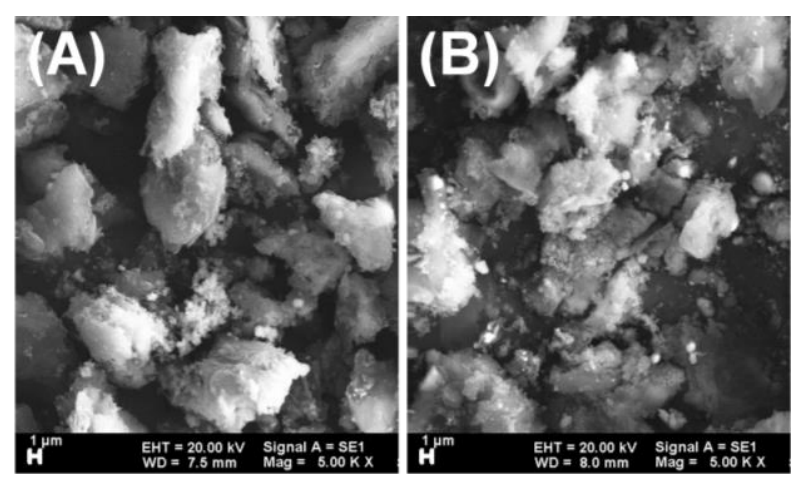

Gambar 1 Hasil pencintraan dengan SEM untuk $\mathrm{Fe}_{3} \mathrm{O}_{4} / \mathrm{C}$ (A) dan $\mathrm{Fe}_{3} \mathrm{O}_{4} / \mathrm{C}-\mathrm{NH}_{2}$ (B)

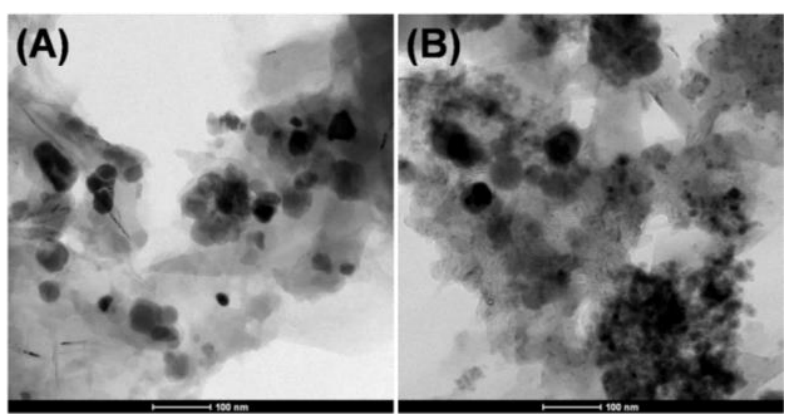

Gambar 2 Hasil pencintraan dengan $\mathrm{TEM} \mathrm{Fe}_{3} \mathrm{O}_{4} / \mathrm{C}(\mathrm{A})$ dan $\mathrm{Fe}_{3} \mathrm{O}_{4} / \mathrm{C}-\mathrm{NH}_{2}$ (B)

Hasil analisa kuantitatif EDX dari nanomaterial $\mathrm{Fe}_{3} \mathrm{O}_{4} / \mathrm{C}$ dan $\mathrm{Fe}_{3} \mathrm{O}_{4} / \mathrm{C}-\mathrm{NH}_{2}$ ditunjukkan oleh Tabel 1. Dari hasil analisa EDX dapat diketahui bahwa karena adanya penambahan elemen baru $\mathrm{N}$ yang berasal dari amonia, prosentase kandungan elemen utama yakni $\mathrm{C}$ dan $\mathrm{O}$ dalam $\mathrm{Fe}_{3} \mathrm{O}_{4} / \mathrm{C}$ sedikit lebih tinggi yaitu berturut-turut sebesar 66,49 dan 21,77 \% daripada dalam $\mathrm{Fe}_{3} \mathrm{O}_{4} / \mathrm{C}-\mathrm{NH}_{2}$ berturut-turut sebesar 65,43 dan 25,19\%. Sebaliknya, prosentase kandungan elemen $\mathrm{Fe}$ dalam $\mathrm{Fe}_{3} \mathrm{O}_{4} / \mathrm{C}$ lebih kecil dibandingkan dalam $\mathrm{Fe}_{3} \mathrm{O}_{4} / \mathrm{C}-\mathrm{NH}_{2}$ diikuti oleh penambahan elemen $\mathrm{N}$ sebanyak $1,36 \%$. Penambahan elemen nitrogen diduga berasal dari efek penambahan amonia dalam media cair arc discharge yang berkontribusi pada modifikasi permukaan nanomaterial. Jika diasumsikan bahwa semua elemen Fe berada sebagai $\mathrm{Fe}_{3} \mathrm{O}_{4}$ maka dengan kalkulasi persen berat molekul, Fe dalam $\mathrm{Fe}_{3} \mathrm{O}_{4} / \mathrm{C}$ dan $\mathrm{Fe}_{3} \mathrm{O}_{4} / \mathrm{C}-\mathrm{NH}_{2}$ diestimasikan berikatan dengan elemen $\mathrm{O}$ berturut-turut sebanyak 2,180\% dan $3,05 \%$. Dengan demikian terdapat kelebihan elemen oksigen yang diduga berikatan secara kovalen dengan elemen lain yaitu $\mathrm{C}$ pada struktur karbon grafit yang membentuk $\mathrm{C}-\mathrm{OH}$ atau $\mathrm{C}-\mathrm{O}$ dan $\mathrm{C}=\mathrm{O}$ sebesar $25,73 \%$ dan $22,13 \%$ berturut-turut untuk $\mathrm{Fe}_{3} \mathrm{O}_{4} / \mathrm{C}$ dan $\mathrm{Fe}_{3} \mathrm{O}_{4} / \mathrm{C}-\mathrm{NH}_{2}$.

Tabel 1. Hasil analisis kuantitatif dari EDX

\begin{tabular}{ccc}
\hline Elemen & $\begin{array}{c}\mathrm{Fe}_{3} \mathrm{O}_{4} / \mathrm{C} \\
(\mathrm{Wt} \%)\end{array}$ & $\begin{array}{c}\mathrm{Fe}_{3} \mathrm{O}_{4} / \mathrm{C}-\mathrm{NH}_{2} \\
(\mathrm{Wt} \%)\end{array}$ \\
\hline $\mathrm{C}$ & 66,49 & 65,43 \\
$\mathrm{O}$ & 27,77 & 25,19 \\
$\mathrm{Fe}$ & 5,74 & 8,01 \\
$\mathrm{~N}$ & - & 1,36 \\
Total & 100,00 & 100,00 \\
\hline
\end{tabular}

Karakterisasi FTIR bertujuan untuk mengetahui modifikasi permukaan dari nanomaterial $\mathrm{Fe}_{3} \mathrm{O}_{4} / \mathrm{C}$. Keberhasilan modifikasi permukaan ditandai dengan adanya gugus fungsi yang mengandung nitrogen. Hasil analisis spektra dari nanomaterial $\mathrm{Fe}_{3} \mathrm{O}_{4} / \mathrm{C}$ dapat dilihat pada Gambar 3. 


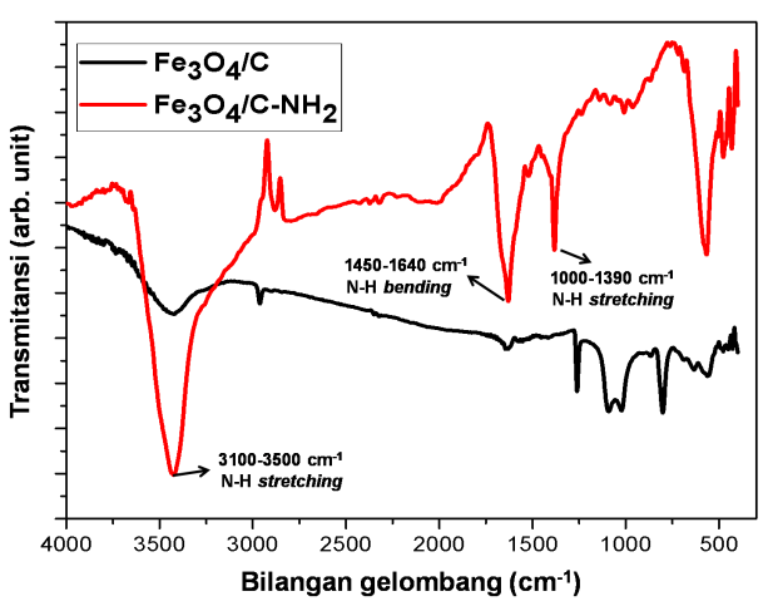

Gambar 3. Spektra FTIR dari nanomaterial $\mathrm{Fe}_{3} \mathrm{O}_{4} / \mathrm{C}$ dan $\mathrm{Fe}_{3} \mathrm{O}_{4} / \mathrm{C}-\mathrm{NH}_{2}$

Berdasarkan Gambar 3. dapat dilihat bahwa pada daerah bilangan gelombang 460-560 $\mathrm{cm}^{-1}$ menunjukkan adanya stretching dari ikatan $\mathrm{Fe}-\mathrm{O}$, pada daerah bilangan gelombang 1000-1300 $\mathrm{cm}^{-1}$ mengindikasikan adanya serapan $\mathrm{C}-\mathrm{O}$ alkohol, pada daerah bilangan gelombang $1400 \mathrm{~cm}^{-1}$ mengindikasikan adanya serapan $\mathrm{C}-\mathrm{C}$ stretching, pada daerah bilangan gelombang 1650-1680 $\mathrm{cm}^{-1}$ mengindikasikan adanya serapan $\mathrm{C}=\mathrm{C}$ stretching, pada daerah bilangan gelombang 1660-1690 cm mengindikasikan adanya serapan $\mathrm{C}=\mathrm{O}$ stretching, pada daerah bilangan gelombang 2850-3000 $\mathrm{cm}^{-1}$ mengindikasikan adanya serapan $\mathrm{C}-\mathrm{H}$ stretching alkana yang berasal dari grafit, pada daerah bilangan gelombang 650-1000 $\mathrm{cm}^{-1}$ mengindikasikan adanya serapan $\mathrm{C}-\mathrm{H}$ bending dari alkena dan pada daerah bilangan gelombang 3200-3400 $\mathrm{cm}^{-1}$ mengindikasikan adanya serapan $\mathrm{O}-\mathrm{H}$ alkohol dan fenel. Dibandingkan dengan $\mathrm{Fe}_{3} \mathrm{O}_{4} / \mathrm{C}$, $\mathrm{Fe}_{3} \mathrm{O}_{4} / \mathrm{C}-\mathrm{NH}_{2}$ memberikan serapan baru spektra pada daerah bilangan gelombang 1000-1390 $\mathrm{cm}^{-1}$ mengindikasikan adanya serapan $\mathrm{C}-\mathrm{N}$ amina, pada daerah bilangan gelombang 1450-1640 $\mathrm{cm}^{-1}$ mengindikasikan adanya serapan $\mathrm{N}-\mathrm{H}$ bending, dan pada daerah bilangan gelombang 3100-3500 $\mathrm{cm}^{-1}$ mengindikasikan adanya serapan $\mathrm{N}-\mathrm{H}$ stretching amina. Hal ini mengindikasikan bahwa nanomaterial $\mathrm{Fe}_{3} \mathrm{O}_{4} / \mathrm{C}$ telah berhasil termodifikasi oleh gugus $\mathrm{NH}_{2}$ yang berasal dari amonia sehingga menjadi nanomaterial $\mathrm{Fe}_{3} \mathrm{O}_{4} / \mathrm{C}-$ $\mathrm{NH}_{2}$.

Keberhasilan modifikasi nanomaterial dalam penelitian ini sesuai dengan hasil penelitian sebelumnya menggunakan metode submerged arc discharge dalam media cair dengan penambahan larutan urea [13, 14] dan etilendiamin [15]. Ketiga penelitian tersebut menunjukkan bahwa munculnya serapan $\mathrm{N}-\mathrm{H}$ stretching amina berada pada daerah bilangan gelombang $3400 \mathrm{~cm}^{-}$ 1 dan serapan C-N amina pada daerah bilangan gelombang 1450-1640 $\mathrm{cm}^{-1}$. Variasi media cair yang dilakukan terbukti dapat mempengaruhi karakter permukaan dari nanomaterial hasil arc discharge sehingga memberikan hasil yang berbeda.
Berdasarkan analisa FTIR dan SEM nanomaterial $\mathrm{Fe}_{3} \mathrm{O}_{4} / \mathrm{C}$ berhasil termodifikasi oleh penambahan amonia menjadi nanomaterial $\mathrm{Fe}_{3} \mathrm{O}_{4} / \mathrm{C}-\mathrm{NH}_{2}$. Hal ini terjadi karena adanya perubahan ikatan dan struktur serta komposisi dari nanomaterial yang terbentuk sehingga terjadi perubahan orientasi gugus $-\mathrm{NH}_{2}$ yang akan berinteraksi dengan media cair (akuades dan etanol 50\%) yang mengakibatkan perubahan sifat dari nanomaterial yang semula bersifat hidrofobik menjadi hidrofilik. Terdapat dua kemungkinan mekanisme menempelnya gugus fungsi $-\mathrm{NH}_{2}$ pada permukaan nanomaterial yang terbentuk, yaitu secara adsorpsi melalui interaksi van der waals dimana gugus fungsi menempel pada permukaan nanomaterial. Selain itu, gugus fungsi juga dapat menempel pada permukaan nanomaterial melalui ikatan kovalen. Hal yang sama juga dilaporkan Sari [9] bahwa gugus fungsi yang menempel pada permukaan nanomaterial dipengaruhi oleh media cair yang digunakan. Usulan mekanisme reaksi dapat ditunjukkan pada Gambar 4. Penempelan gugus amina diyakini terjadi pada zona plasma saat arc antar dua elektroda. Elektron bebas saat terjadinya plasma mengionisasi $\mathrm{NH}_{3}$ menjadi $\mathrm{NH}_{3}{ }^{+}$. Lebih lanjut, terbentuknya $\mathrm{NH}_{3}{ }^{+}$menginisiasi terbukanya ikatan rangkap pada struktur grafit dan kemudian gugus amino berikatan secara kovalen dengan C sebagaimana yang ditunjukkan dalam Gambar 4.

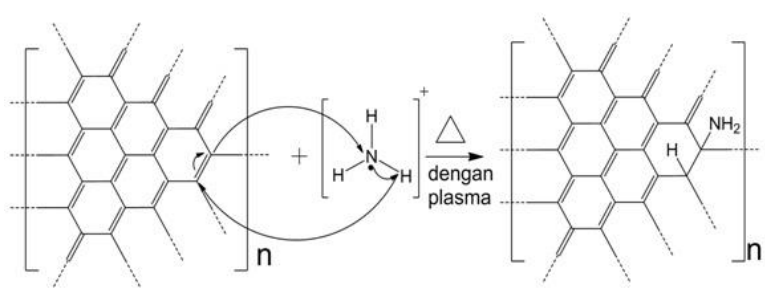

Gambar 4. Mekanisme ikatan kovalen antara gugus fungsi amino pada karbon

\section{Kesimpulan}

Penambahan amonia pada media cair dalam proses arc discharge berpengaruh terhadap karakteristik permukaan material $\mathrm{Fe}_{3} \mathrm{O}_{4} / \mathrm{C}$ yang terbentukyakni adanya penambahan gugus amino $-\mathrm{NH}_{2}$ yang diduga terikat secara kovalen pada karbon. Hal ini diindikasikan dari serapan ikatan $\mathrm{C}-\mathrm{N}$ dan $\mathrm{N}-\mathrm{H}$ yang teramati pada spektrum FTIR. Selain itu, keberadaan elemen N diperkuat dengan analisis unsur dengan EDX yang menujukkan secara signifikan penambahan $\mathrm{N}$ sebesar 1,36 \%Wt. Selain itu, hasil analisis dengan SEM dan TEM menunjukkan bahwa nanomaterial yang diperoleh memiliki struktur sperikal dan teratur, dimana penambahan amonia, sebagian nanokomposit hasil sintesis yang terbentuk memiliki ukuran yang lebih kecil.

\section{Ucapan terimakasih}

Ucapan terimakasih ditujukan kepada Kementerian Riset, Teknologi, dan Pendidikan Tinggi Republik Indonesia (Kemenristekdikti RI) atas pendanaan riset 
untuk Grant Riset 474/UN27.21/PM/2018 dan 543/UN27.21/PP/2018.

\section{Daftar Pustaka}

[1] Teguh Endah Saraswati, Akihisa Ogino, Masaaki Nagatsu, Plasma-activated immobilization of biomolecules onto graphite-encapsulated magnetic nanoparticles, Carbon, 50, 3, (2012) 1253-1261 https://doi.org/10.1016/j.carbon.2011.10.044

[2] Manuel Arruebo, Rodrigo Fernández-Pacheco, M. Ricardo Ibarra, Jesús Santamaría, Magnetic nanoparticles for drug delivery, Nano Today, 2, 3, (2007) 22-32 http://dx.doi.org/10.1016/S17480132(07)70084-1

[3] Jae-Hyun Lee, Ji-wook Kim, Jinwoo Cheon, Magnetic Nanoparticles for Multi-Imaging and Drug Delivery, Molecules and Cells, 35, 4, (2013) 274-284 http://dx.doi.org/10.1007/s10059-013-0103-0

[4] Hassan Karami, Fariba Goli, Juliet Ordoukhanian, Synthesis of Magnetite/Hematite/Iron Nanocomposites by the Low Voltage Arc Discharge in Water in the Presence of External Magnetic Field, International Journal of Electrochemical Science, 11, (2016) 3074-3085

[5] B. Ankamwar, T. C. Lai, J. H. Huang, R. S. Liu, M. Hsiao, C. H. Chen, Y. K. Hwu, Biocompatibility of $\mathrm{Fe}_{3} \mathrm{O}_{4}$ nanoparticles evaluated by in vitro cytotoxicity assays using normal, glia and breast cancer cells, Nanotechnology, 21, 7, (2010) 075102

[6] V. B. Barbeta, R. F. Jardim, P. K. Kiyohara, F. B. Effenberger, L. M. Rossi, Magnetic properties of $\mathrm{Fe}_{3} \mathrm{O}_{4}$ nanoparticles coated with oleic and dodecanoic acids, Journal of Applied Physics, 107, 7, (2010) 073913 http://dx.doi.org/10.1063/1.3311611

[7] Patimah Patimah, Teguh Endah Saraswati, Pengaruh Suhu Kalsinasi Pada Sifat Kemagnetan Material Besi Oksida Hasil Elektrolisis, Jurnal Kimia dan Pendidikan Kimia, 1, 3, (2016) 149-156

[8] Eun Hee Kim, Yangkyu Ahn, Hyo Sook Lee, Biomedical applications of superparamagnetic iron oxide nanoparticles encapsulated within chitosan, Journal of Alloys and Compounds, 434-435, (2007) 633-636 https://doi.org/10.1016/j.jallcom.2006.08.311

[9] Qian Gao, Fenghua Chen, Jilin Zhang, Guangyan Hong, Jiazuan Ni, Xiao Wei, Dejun Wang, The study of novel $\mathrm{Fe}_{3} \mathrm{O}_{4} @ \mathrm{Y}-\mathrm{Fe}_{2} \mathrm{O}_{3}$ core/shell nanomaterials with improved properties, Journal of Magnetism and Magnetic Materials, 321, 8, (2009) 1052-1057 http://dx.doi.org/10.1021/cm960157j

[10] Aibing Wu, Xuwei Yang, Hua Yang, Magnetic properties of carbon coated $\mathrm{Fe}, \mathrm{Co}$ and $\mathrm{Ni}$ nanoparticles, Journal of Alloys and Compounds, 513, (2012) 193-201 https://doi.org/10.1016/j.jallcom.2011.10.018

[11] Teguh E. Saraswati, Takafumi Matsuda, Akihisa Ogino, Masaaki Nagatsu, Surface modification of graphite encapsulated iron nanoparticles by plasma processing, Diamond and Related Materials, 20, 3, (2011) $359-363$ https://doi.org/10.1016/j.diamond.2011.01.027
[12] Jana Chomoucka, Jana Drbohlavova, Dalibor Huska, Vojtech Adam, Rene Kizek, Jaromir Hubalek, Magnetic nanoparticles and targeted drug delivering, Pharmacological Research, 62, 2, (2010) 144-149 https://doi.org/10.1016/j.phrs.2010.01.014

[13] Teguh Endah Saraswati, Fitri Nela Sari, Nestri Handayani, Surface Character of Iron Oxide/Carbon Nanoparticles Synthesized by Submerged Arc Discharge Method in Ethanol/Urea Medium, ALCHEMY Jurnal Penelitian Kimia, 13, 2, (2017) 287297 http://dx.doi.org/10.20961/alchemy.13.2.2392.287297

[14] Erlina Arikawati, Pranoto Pranoto, Teguh Endah Saraswati, Preparation of Amine-Functionalized $\mathrm{TiO}_{2}$ /Carbon Photocatalyst by Arc Discharge in Liquid, IOP Conference Series: Materials Science and Engineering, 176, 1, (2017) 012045 https://doi.org/10.1088/1757-899X/176/1/012045

[15] N. Rismana, A. R. Astuti, Y. H. Suselo, M. Anwar, Teguh Endah Saraswati, Preparation of aminemodified $\mathrm{Fe}_{3} \mathrm{O}_{4}$ /carbon nanoparticles by submerged arc discharge in ethylenediamine/ethanol, IOP Conference Series: Materials Science and Engineering, 333, 1, (2018) 012026 https://doi.org/10.1088/1757$\underline{899 X / 333 / 1 / 012026}$ 